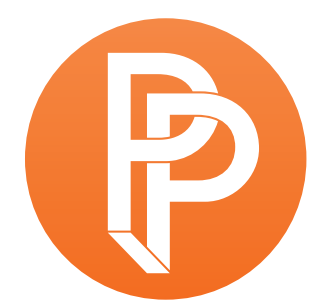

PERFORMANCE

PHILOSOPHY

\title{
A PUTATIVE (PRIVATE) LIFE OF HANNAH ARENDT: BIO-PORTRAITURE AS PERFORMANCE IN THE WORK OF MIRIAM SHENITZER
}

\author{
MICHAELZANK BOSTON UNIVERSITY
}

\begin{abstract}
He [Kafka, acc. to Benjamin] wanted to preserve it [viz. tradition] even though it was not truth, if only for the sake of this "new beauty in what is vanishing [...] and he knew, on the other hand, that there is no more effective way to break the spell of tradition than to cut out the "rich and strange," coral and pearls, from what had been handed down in one solid piece.
\end{abstract}

Hannah Arendt (2019, liii)

I'm speaking to my ancestors. And of course I don't see eye-to-eye with my ancestors. But at the same time I cannot deny their existence.

Jerzy Grotowski and Elizabeth LeCompte in Rebecca Schneider $(2011,111)$

For remembrance, which is only one, though one of the most important, modes of thought, is helpless outside a pre-established framework of reference, and the human mind is only on the rarest occasions capable of retaining something which is altogether unconnected.

Hannah Arendt $(1961,6)$

We are all complicit. There are no bystanders, only degrees of perpetration, as Ute Frevert said in a recent speech. ${ }^{1}$ To speak of bystanders offers exculpation to people who can claim, in hindsight, to have committed no evil. To deny such exculpation demands a new conception of agency. It stipulates that we act even when we think of ourselves as not acting, as being passive, as merely observing the actions of other. I will use this consideration as an entry point to Hannah Arendt's 
insistence on the difference between the public and the private. Historically speaking, "inner emigration" or retreat into privacy appeared as an adequate response to totalitarian rule. But Arendt's insistence on maintaining the difference between private and public cannot be used as an excuse for inaction in the public sphere. What does the difference between public and private mean for us today? I will argue that Arendt's distinction between public and private cannot be maintained in the abstract. It requires concrete "performance" in order to be realized. One such performance I will discuss is that of Miriam Shenitzer's A Putative Life of Hannah Arendt, a faux biographical series of images and objects that confounds the biographical expectation of insight into the intimate and private side of a thinker, turning the gaze back on the viewer and challenging us to reconsider our conceptions of knowledge of individuality and personality in an age of a massive in/voluntary erasure of the boundaries between private and public. It thus restores the ineffability of the individual in form of a public display that disputes access to the life of Arendt. Shenitzer's "putative" biographical portrait of Hannah Arendt thus marks an Arendtian performance of the elusive distinction between private and public.

\section{Difficult freedom²}

Culpability for inaction is not a new concept. The Catholic tradition knows of sins of omission. Similarly, the German legal system encoded the offense of "failure to provide assistance" (unterlassene Hilfeleistung). ${ }^{3}$ The assumption is that if you could have acted, then you ought to have acted. If you can, you ought. The philosopher Immanuel Kant famously turned this sentence around, marking the transition from natural law to idealist ethics: Du kannst, denn du sollst ("You can, because you ought"; see Braun 1975 and Schöndorf 1985). If reason, or rational thought, commands you to do something because it is good, then you ought not to doubt your ability to pursue it. According to some interpreters, Kant's categorical imperative was based on an important corollary, namely, that no one can hold us responsible for the impossible. ${ }^{4}$ The impossible would, in any circumstance, be irrational. Reason would be the measure of the difference between the possible and the impossible. But is it true that we are responsible only for what is possible? Cannot this maxim be turned into a convenient excuse? This seems to me what Hannah Arendt saw in Adolf Eichmann, one of the architects of the so-called "final solution of the Jewish question." According to Eichmann in Jerusalem: A Report on the Banality of Evil (Arendt [1963] 2006), Eichmann had honed the ability to make excuses and exemplified what to Arendt was the perversion of thought into an instrument of self-exculpation. Arendt saw Eichmann as the apex of thoughtlessness in the face of evil. Although her assessment of Eichmann has been called into question in view of Eichmann's diaries (Stangneth 2014), Arendt still has a point. Thought alone can reveal to us the difference between what we can-and therefore ought-to do, and what others expect of us. Contrary to what we might believe, thought is not an instrument of generalization but of concretization. In Heidegger's terms, thought is precisely what drives us to overcome the power of general expectation, or the "man." In contemporary ethics, it is Emmanuel Lévinas, another one of Heidegger's "Jewish children" (see Wolin 2001, 2015) who teaches us to exceed Kant's categorical imperative by making it both concrete and overwhelming. By prioritizing the face of the other, Lévinas teaches us, that the ought, in order to be fully ethical, must extend beyond the possible. 
We must hold ourselves responsible in the face of the impossible. In light of the Holocaust and similar atrocities, the ethical imperative can no longer be limited to the possible, to what may be expected. It is one of the qualities of Arendt's writing that she draws our attention to the daily, rather than extraordinary, occurrences of erasure of humanity, not by ecological cataclysm, but by our complicity in thoughtlessness and facelessness.

We can learn from the writings of Hannah Arendt where to look for those things that prevent us from accepting full responsibility not just for our action but for our inaction. Where does inaction begin? Why is it pervasive? What leads us to adopt habits that advance the demise of the human and hasten the advent of the post-human? Arendt warns us that the human element, the human as such, is being gradually erased, and that we contribute to its erasure. We bring this erasure about by acting thoughtlessly. This sounds like a paradox. How can one act without thought? Is not thoughtlessness a lack of thought and hence a form of inaction? Here we see the parallel between a weak conception of thoughtlessness and the notion of the bystander. The bystander is an actor, as is the one who acts without thought. Thoughtlessness is more than lack of thought. It is a choice, an activity, an erasure rather than the result of inaction. The act of thoughtlessness accomplishes a self-erasure. Like an opiate, it accomplishes oblivion, a happiness without perfection, a forgetting of the most important element that, in the Kantian tradition, indicates our freedom and therefore our humanity. We seem to use our ability to think, the "freedom to be free," only to pervert it, using it to abandon our tenuous selves to mechanisms of unfreedom and the erasure of genuine selfhood. The freedom to think is, to Arendt, the most eminent attestation of our "freedom to be free." A 1967 lecture by Arendt bearing this title was recently issued for the first time in German (Arendt 2018). It became an instant bestseller, a harbinger of the Arendt renaissance now in full swing.

This renaissance comes with perils. Thomas Meyer, the editor of that small book which has had such a remarkable success among contemporary German readers, now warns that Arendt has become all-too-easily available, her life too well-known, the standard narrative about her too familiar for us not to fear that what we think we know will distract or downright prevent us from reading Arendt carefully (Encke 2018). The Arendt myth has become a manner of dehumanizing, namely, de-concretizing and obscuring the private person behind the public mask.

The difference between public and private was essential to Arendt. It is a fundamental imperative that those of us using "social media" violate on a daily basis. We submit our most private experiences to public scrutiny and to corporate abuse, surrendering what truly makes us human to the short-lived and seemingly ever- renewable thrill of exposure in unselfconscious (thoughtless) acts of exhibitionism. It seems as if we are hell-bent on cashing in our social capital without regard to the fact that we are allowing others to commodify what remains of our private lives. We are eagerly dissolving ourselves into data and we take issue with others who resist doing the same with themselves. The exchange value for our loss of privacy consists of what we gain in putative insights into the lives of others. The measure of "justice" on social platforms consists in the balance between "followers" and "following," in other words, in popularity. We know of the dire 
psychological consequence of this new exchange economy on young people, which therapists refer to as social media addiction.

\section{Miriam Shenitzer's A Putative Life of Hannah Arendt}

At its best, visual art can perform an interruption of such trends. In the following I will describe and interpret a particular series of work that uses Hannah Arendt as a (putative) point of reference or, perhaps more accurately, as a cipher open to interpretation, while interfering with our assumptions about biographic information and its function in the economy of "data" (literally, things that are "given"). Shunning conventional "givens"-such as dates of birth and death, photographs, documents, and other tokens that correlate a particular life to generally assumed realities-Shenitzer's putative life of Hannah Arendt confronts the viewer with drawn images, displayed on drawn frames, and augmented by drawn or found objects, accompanied by labels that falsely suggest connection with, and significance for, a life, putatively that of Hannah Arendt.

Miriam Shenitzer's A Putative Life of Hannah Arendt uses the encomiastic expectations associated with the "lives of great men" to accomplish a thorough interrogation of the categories of knowledge we bring to this and, by extension, any iconic figure. The title of Shenitzer's installation of pseudobiographical drawings and faux-authentic objects clearly enunciates the performance of an epistemic aporia. By rendering the expected "life of Hannah Arendt" putative, the artist draws the viewer into a vexing situation. At an exhibition and seminar-style discussion of this work, one of the audience members ended up exasperated, asking: "What is the percentage of true information about Arendt presented by this work?" In other words, the viewer was disturbed by the "action" of the display, which invokes a name while both denying and providing access to its presence. As in classical aesthetic theory of drama, the effect is interactive. The performance accomplished by this show takes place in the interaction between words, images, and audience response. The visual work aims to trigger a reaction, similar to the moment of recognition (anagnorisis) experienced by the audience that completes the tragedy acted out on a stage, but without any real catharsis. More open than its classical antecedent, though no less shrouded in mystery, the interaction stimulated by the visual display holds no clear intention or demarcation of its success or failure. The artwork provokes, but does not prefigure or guide, the thought of the viewer. It is neither leading nor misleading. I will attempt to consider this performative accomplishment of a biographic suggestio falsi as an Arendtian admonition to heed the boundary between public and private lives: a simultaneous revealing and concealing of ineffable individuality accomplished by staging the life on display as identifiable and typical, yet utterly concrete and particular.

In the following I will describe the organization of the show, its biographical taxonomy, and some of the images, artifacts, and the "captions" that identify what is depicted as putatively related to Arendt and ostensibly provides access to the "life" one might piece together from the images, objects, and verbal cues on display. The basis for these observations will be the documentation of an exhibition held at the Elie Wiesel Center for Jewish Studies at Boston University that opened on May 27, 2018, and was on display until the middle of August of 2018 ("About A Putative Life of Hannah Arendt"). What interests me in particular is the artist's attention to the details of private life. 
Some biographic details appear related to the actual life of Arendt (e.g., her relationships as a university student), while others seem to convey cryptic messages about a private life that could have been Arendt's but actually wasn't, very much like the personal messages and memories encrypted in the paintings of Gerhard Richter who admits that many of his paintings convey hidden personal meanings that only the painter himself is aware of, while leaving the audience to project their own assumptions onto the canvas, or reflect on a painting's aesthetic or social meanings. Like Richter, Shenitzer leaves no obvious hint in the images to their private meanings except the images, objects, and words themselves. Nor does she indicate anywhere that the life depicted is ever any other than that of a putative Hannah Arendt.

The panels of images and objects displayed nearby (at the BU exhibit these were on the surfaces of bookcases located beneath the walls) are organized by themes and roughly follow the typical chronology of an actual biography from childhood to adulthood. The drawn titles of the eleven panels of images (dictated by the characteristics of the space, the former boardroom of the university, the grand parlor of a late nineteenth-century patrician residence, a locale that evokes putative bourgeois European origins) read as follows:

The Apple doesn't Fall Far from the Tree: Family and its influence on Arendt's Political Philosophy

A force to be Reckoned with: The Women in Arendt's Family

Strange Bedfellows: Hannah Arendt and Religion

Fuchs, Du hast den Ganz ${ }^{6}$ Gestohlen: Arendt and her Caregivers.

A Mixed Blessing: Childhood and the Mediation of Power

Ach, Du lieber Augustin: Arendt's Teenage Years

Hoppe, Hoppe, Reiter: Hannah Arendt's Love of Sports

Wer ist der Mann da, auf der Verandah? The Men in Arendt's Life

Don't Mean a Thing, If it Ain't Got That Swing: Hannah Arendt \& the Arts

An Uneasy Truce: Hannah Arendt and the Academy

Which Promised Land: America or Israel?

The range of subjects shows that this putative life of Hannah Arendt is limited to the subject's formative years. Little attention is given to a later career, to marriage, old age, or death, where the putative life would have had to compete with the all-too-well known facts of an actual life. The artistic faux-biographer thus evokes the genre of the "anecdotal" biography of famous people, a life, character, or personality as revealed from hidden or private sources, sources that may have remained unmentioned by the official or authorized biographers. An antique suitcase on display suggests the serendipity of preservation of the artifacts of a life that was likely interrupted by the 
vicissitudes of migration, as suggested by the last panel, which leaves the question of Hannah Arendt's destiny without a definite answer; for example, four out of the six images the artist chose for the last panel of the exhibition at Boston University depict personages from among "Hannah Arendt's" circle who settled in Palestine, and only two relate to an American experience of Hannah Arendt, foregrounding the road not taken. The biography thus leads up to the mid-century disruption of European Jewish lives without making it explicit. It encapsulates and suggests a world that was lost.

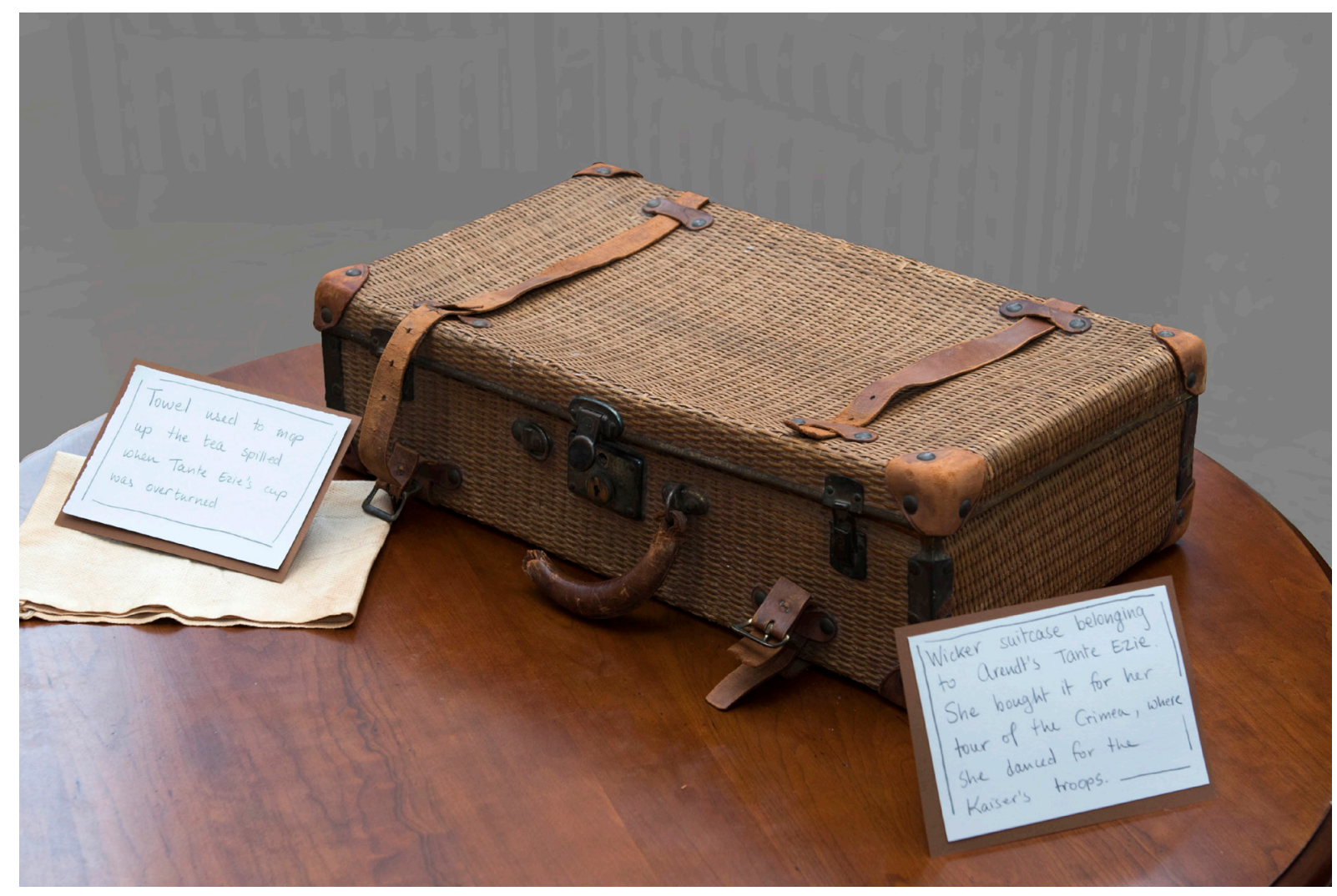

Figure 1: Wicker Suitcase belonging to Arendt's Tante Ezie. She bought it for her tour of the Crimean, where she danced for the Kaiser's troops. (Photo: Bill McCormack)

The visual style and wording of the captions by which the panels are organized suggests silent movie panels or panels carried across the stage between the acts of a variety show, art forms associated with the historical period of the putative life being depicted. At the same time, the fact that the panels are drawn in the same style as the captions that go with, and sometimes are part of, the drawings introduces an element of irony, as ordinarily captions or titles are not part of an image on display in an exhibition but represent the curatorial voice, offering authoritative interpretation. The show intentionally blurs the lines between image and objects, captions and images, artistic imagination and sober curatorial annotation. It is, in that sense, a kind of Gesamtkunstwerk of denied authenticity. 


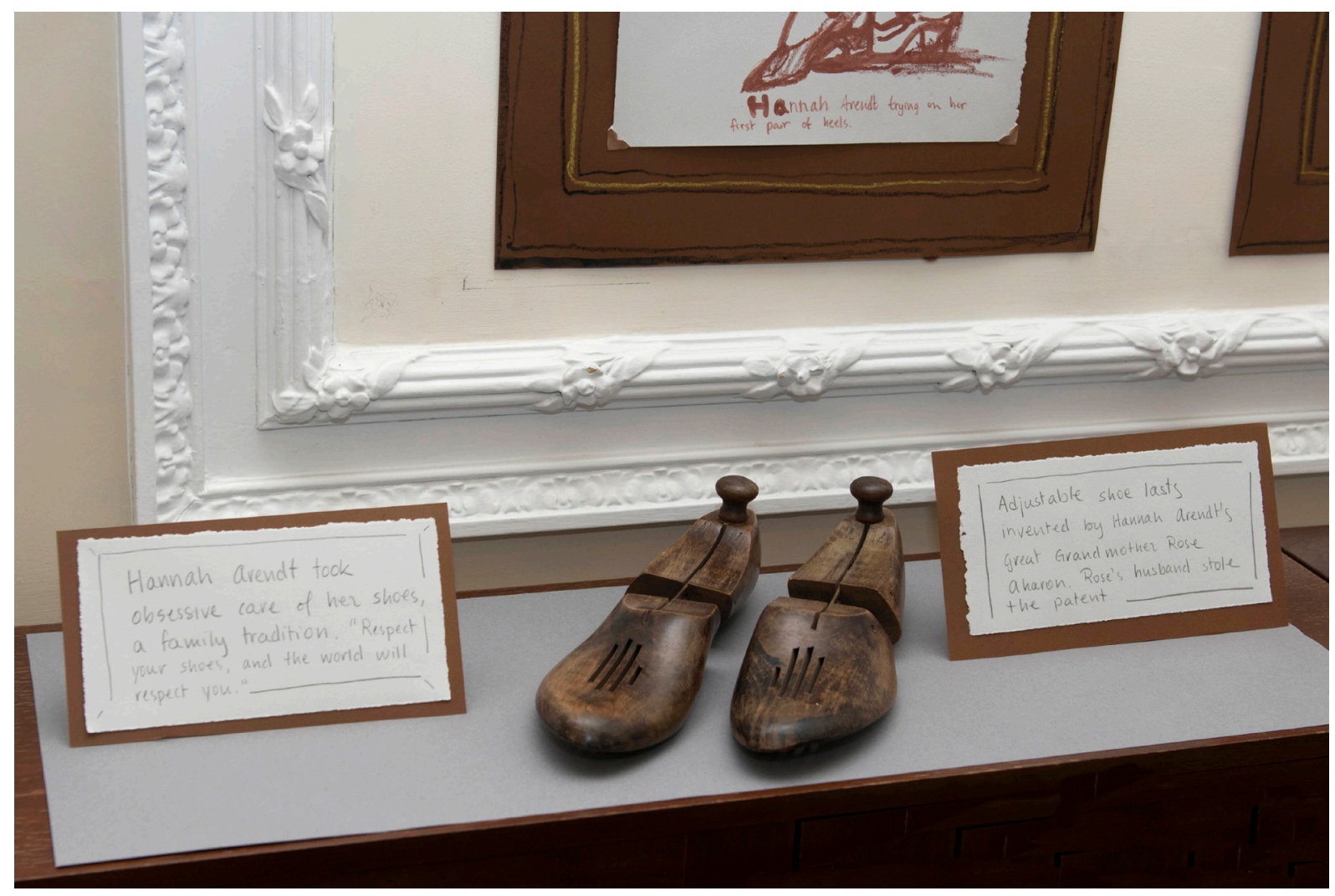

Figure 2: Adjustable shoe-lasts invented by Hannah Arendt's Great Grandmother Rose Aharon. Rose's husband stole the patent. (Photo: Bill McCormack)

The panel of family antecedents invokes the kind of historical photographs we either possess ourselves or have seen in the homes of others, those collections of framed photographs, sometimes faded or damaged, that are part of our own western bourgeois version of ancestor worship. The artist uses grey paper and monochromatic colors for the drawings and their captions, evoking materials that have faded with time, or black and white films from the early $20^{\text {th }}$ century. At the same time, each family has its idiosyncratic characters, and ancestral pictures often go with stories that summarize the character, as in the name-cum-title of a gallery of pseudo-noble ancestors that can be easily spoofed. The antedecents of Shenitzer's putative Arendt are her (Great) Great Grandfather Friedrich Aaron (the caption mistakenly refers to him as Great Grandfather), depicted in $18^{\text {th }}$-century costume and identified as the "inventor of the stacked heel," Great Grandmother Rose Aharon, née Finck, inventor of the adjustable shoe-last, and Great Grandfather Moses Aharon, who "never lived up to his father's expectations and ended up claiming the patents for his wife's inventions," among others.

Jarringly, on display nearby is a set of adjustable wooden shoe stretchers accompanied by two labels, one suggesting that "Hannah Arendt took obsessive care of her shoes, a family tradition;" a claim backed up by a saying, apparently handed down in the family: "Respect your shoes, and the world will respect you." The other label connects between the image caption for Rose Aharon and 
the objects on display: "Adjustable shoe lasts invented by Hannah Arendt's Great Grandmother Rose Aharon. Rose's husband stole the patent." The circularity of the references and the solidity (and antique character) of the object on display create cohesion and verisimilitude, and thus offer a hermetic moment of initiation into a true/false family tradition. What is true about it is not disclosed. The claim made by the drawn image, which is not a historical photograph and hence lacks all authenticity, though not plausibility, is backed up by the object, which is incorrectly called a "shoe last" but looks authentic. The result is a précis of the show as a whole: a circle of hermeneutical confusions about what is real or true and what isn't.
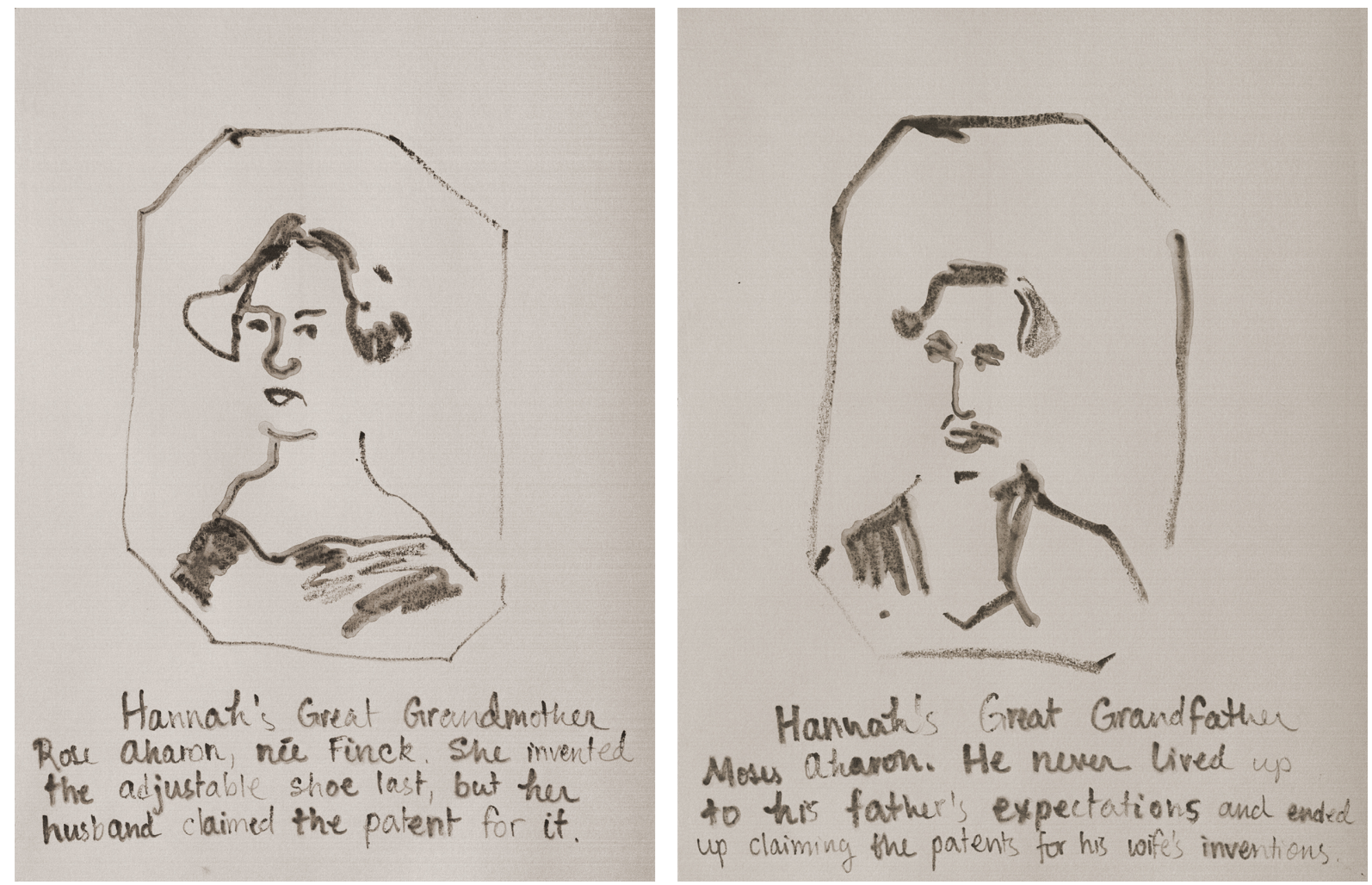

Figure 3: Hannah's Great-Grandparents (photo: Miriam Shenitzer 2019)

Significantly missing among the antecedents and from the women in Hannah Arendt's putative family is an image of her mother, who is never depicted, although she is mentioned in some of the captions. (For example, she is mentioned in the caption for Madame Solinka, the medium regularly consulted by Hannah Arendt's mother.) On the other hand, the artist's own mother makes a cameo appearance in one of the images of the "Sports" panel where she is depicted as a swimmer. The caption names "Sarah Pomeranc," but the uninitiated viewer would not know that the woman looking back at her confidently was the artist's mother. The caption further states that Sarah "easily defeated Hannah Arendt in the Women's Triathlon" and "called Hannah 'that Yecke."' While denying access to "Hannah Arendt," the rich tapestry of intimate images in fact provides a kaleidoscopic inventory of the artist's own imagination, populated by partly actual and partly invented characters and experiences. 


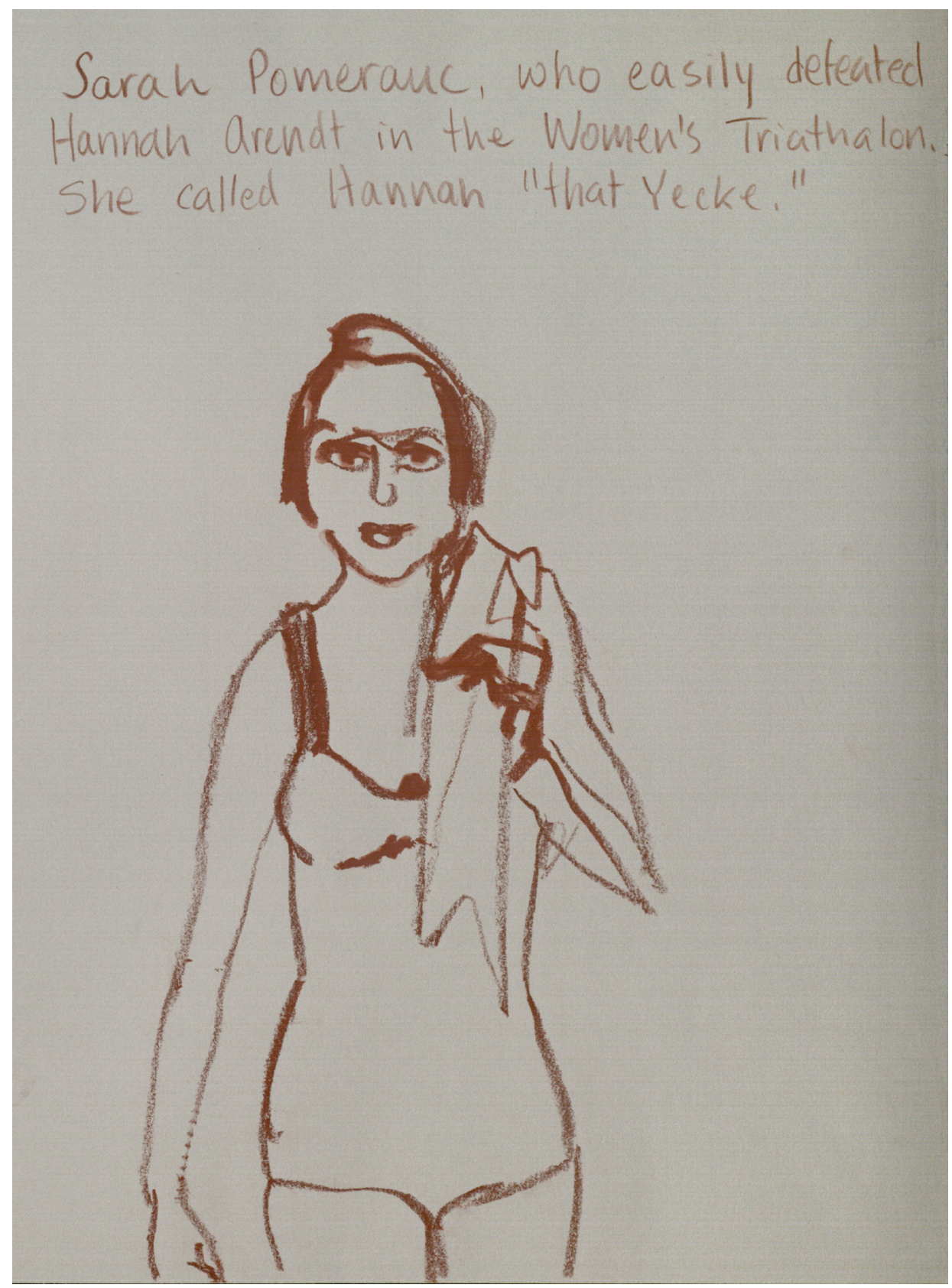

Figure 4: "Sarah Pomeranc, who easily defeated Hannah Arendt in the women's triathalon. She called Hannah 'that Yecke'" (photo: Miriam Shenitzer 2019)

The show thus issues a veiled invitation to engage with the very private inner life and re/collections of the artist herself using a narrative superimposed on the figure of Hannah Arendt. This hermeneutical double-take thus preserves the privacy of the artist who lavishly draws from her own experience and from objects collected over time and imbued with personal meaning, while forestalling all curiosity that would attempt to know the real Hannah Arendt better than she knew herself. 
Shenitzer's faux-biographical portraiture puts a life on display, though not the one the viewer is invited, tongue-in-cheek, to imagine. The putative "Hannah Arendt" is individualized, but she is also thoroughly hidden. Just as the subject's mother never appears, the putative Hannah Arendt also rarely appears in person, and only in forms that disallow the formation of a clear image. Instead, we get pictures, as if from a neglected drawer, a cigar-box with the discards that didn't make it into any official album, or an album assembled from the pictures that somehow made it across the historical abyss that is never mentioned. In place of a portrait of Hannah Arendt we get a thick, though veiled, image of the artists' own memory fragments and jumbled references that are so typical of our family traditions: half-truths and barely remembered bits and pieces, things they carried, and that are all that we have to pass on to the next generation. The "putative life of Hannah Arendt" affirms the fragmentary character of our personal lives and underscores the disjointedness of disrupted lives.

My purpose was to show the subterranean connections between Shenitzer's "putative life of Hannah Arendt" and Hannah Arendt's insistence on maintaining the boundaries between public and private lives as a condition of freedom, dignity, and humanity. In place of using readily

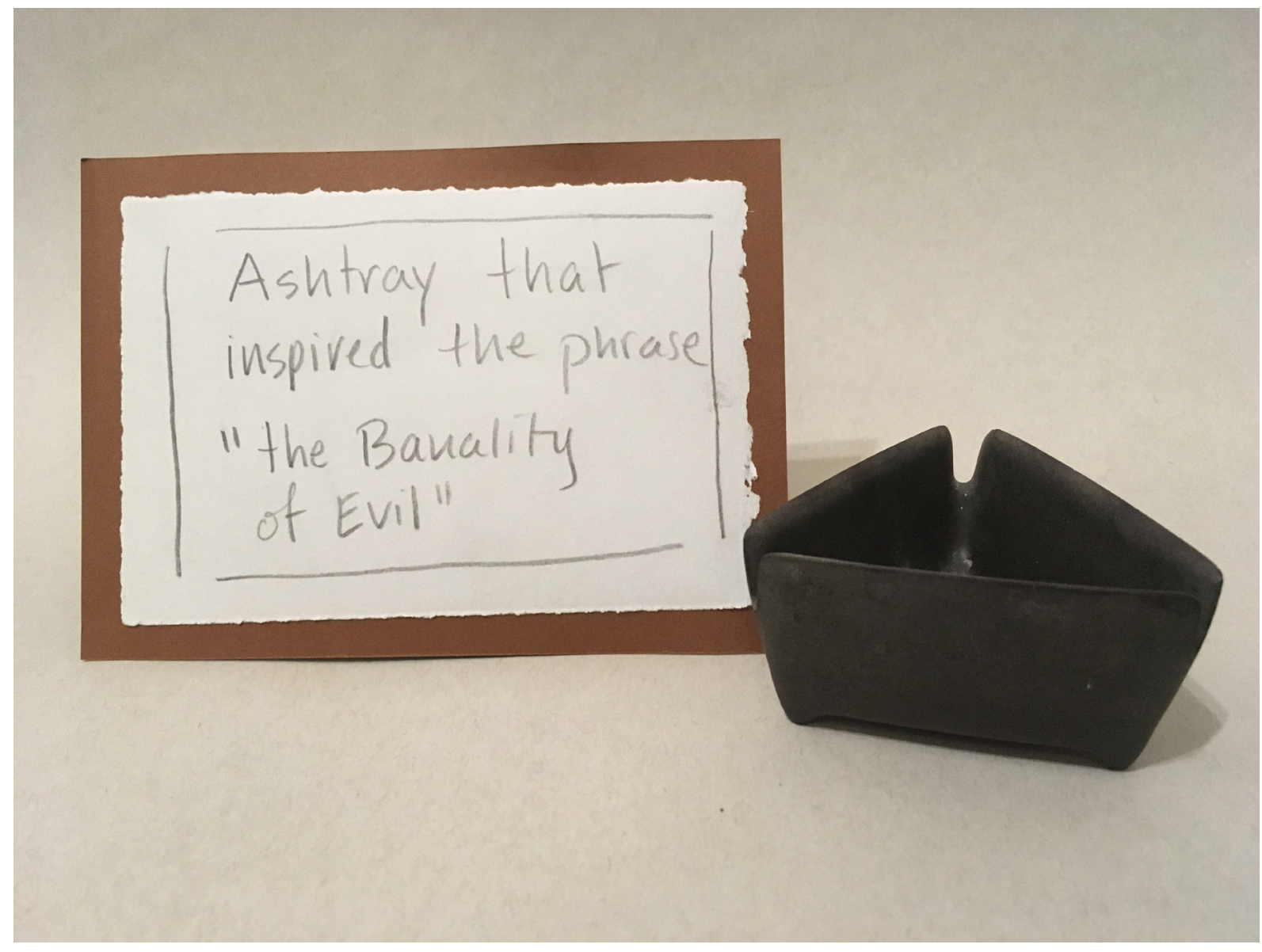


available, but ultimately facile and essentially questionable biographical conventions, Shenitzer's work draws attention to our essential ignorance of any but our own life. As we traverse the putative life on display, we realize just how much our lives are lived with others, given and determined by others, by the personages that populate and make our reality. The life at the center emerges from the negative space, from the undepicted, in the interstices between the remembered and forgotten, the putative and the real.

The assembled images and objects constitute an "archive" of sorts. As Jacques Derrida writes in Archive Fever (1996), the arche of the archive alludes to both commencement and commandment. The title of the visual archive, A Putative Life of Hannah Arendt, provides the directive on how to view the images. Like all historical evidence from which we attempt to retrieve or reconstruct the past, the visual archive of this putative life resists our attempts to impose prior knowledge, or prior assumptions, on the being that appears in the images, artifacts, and captions. We are to suspend our assumptions and allow for an encounter of a different life, a different personage, a different way of telling a story to take place.

Shenitzer's putative life of Hannah Arendt intuits the "relatedness" of the self that Arendt sought to reassert in her thinking about what it means to be human. This "related" self-as Andrew Benjamin (2018) argues in a recent paper-"twists itself free from what [...] Heidegger criticized as a 'metaphysics of subjectivity"' (215). In place of the isolated self of the thinker, often invoked in iconic photographs that might appear on book covers, Shenitzer's Arendt appears in an array of imagined figures and coincidental configurations. In the manner of a family album that neither fails nor succeeds in documenting the emergence of a character, while inadvertently documenting the styles, social habits, and historical contexts of a life, Shenitzer's drawings, artifacts and inscriptions capture the milieu, the aura, and the possibilities inherent in a particular time and a particular place. The particular time and particular place evoked in the putative life series is that of the 1920s and 30s, somewhere in Central Europe, somewhere in the "unbearable lightness of being," as Milan Kundera titled his breakout novel about private lives on the margins of the 1968 Prague Spring. The putative life of Hannah Arendt is constructed from memory fragments of unknown origins that are nevertheless real and suggest familiarity. We become acquainted with a persona, a character, without being entirely sure of the knowledge conferred by this archive.

Defying the biographical convention that the early life of a personage adumbrates their eventual greatness, Shenitzer depicts the putative early life of Hannah Arendt as a set of ordinary moments, serendipitously captured and preserved in a visual archive of seeming trivia. This vindication of the everyday, the intimate, the fleeting moment, the odd relationship on the margins of a life, captures the tapestry of emotions and attachments that are often ignored, emotions of joy and disappointment and attachments of friendship and distrust that are here foregrounded as formative and normative in how we turn out as human beings. By retrieving, albeit virtually, the putative life of Hannah Arendt, Shenitzer's visual archive serves as a stage for the life of the emotions. Emotions and encounters constitute links and bonds between individuals where concepts and classifications fail us. 
By creating the simulacrum of a putative life Shenitzer both asserts authority of access and memory preservation as well as relinquishes all claims to authoritative depiction. Gesturing at the ineffability of the true self, the putative life of Hannah Arendt denies as well as affirms access to the persona at the center of the series. The artist is thus in equal parts mystagogue and demystifier, enchanter and disenchanter.

\section{The artist as collector}

In the passage from Arendt's introduction to her edition of Walter Benjamin's Illuminations that I placed at the beginning of this essay, Arendt illustrates Benjamin's obsession with collecting books, many of which he proudly acknowledged not to have read, and quotations, with a view to pursuing an ideal of writing that would consist exclusively of quotations. Arendt perceptively describes what Benjamin shared with Franz Kafka (and, one might add, with Leo Strauss [2002, 69-70, passim]), which is a realization that dawned on Benjamin only gradually, namely, that the loss of the authority that tradition had previously bestowed on revealed or uncovered (unconcealed, unverborgen) truths had left truth bereft of a certain "consistence" (Arendt 2019, li). To Benjamin's chapter in which these considerations unfold, Arendt gives the title "Perlentaucher" or "The Pearl Diver," which is her metaphor for the collector. As a thinker of the modern condition (see Arendt 1958, 1961), Arendt describes not only the fracturing of the beautifully unified world of pre-modern humanity but interprets the works of liminal modernists like Benjamin and Kafka who articulate the unraveling of the consistence of the modern project from their own socially marginal perspective as members of a tribe of colonized colonizers and a "pariah" people (see Arendt 1978).

In Arendt's reading of Benjamin, the fracturing of tradition, and of the abeyance of the function of tradition as providing "consistence" to received truths, finds expression in literary work that is more poetic and aphoristic than prosaic, linear, or systematic. Arendt thereby explains Benjamin's seeming failure to produce anything larger or more sustained than essays that are at best to be classified as "criticism." The form and style of his writing is thus a true reflection of how he perceives and works through the phenomena he engages with. In terms of perception and representation, what is essential here is Arendt's attention to the difference between metaphor and allegory, a subject she discusses in connection with Benjamin's friendship with Brecht and his distance from Adorno who rightly, as Arendt believes, dismissed Benjamin's Marxism as "vulgar," i.e., as lacking an appreciation for dialectics. Arendt sees Benjamin as someone who appreciated the metaphoric character of all things, the smaller the better, by which he turns his back on the preference for allegory, common among rationalist philosophers of all stripes, for whom essence precedes existence.

Much like Benjamin, as described by Arendt, The Putative Life of Hannah Arendt created by Shenitzer revels in the miniature, the faux objets d'art, as a form of representation. Her work presupposes not so much the difficulty of retrieving tradition in general but rather the denial of return of a past shattered by the Holocaust. There is nothing "handed down in one solid piece" and even the "coral and pearls" on display, as if rescued from a shipwreck, are recognizably inauthentic (Arendt 2019, lii). The reason this works, or rather the effect achieved by attributing the images, objects, and 
memory fragments "preserved" and put on display in the labels to a putative life of Hannah Arendt, is that "Hannah Arendt" provides a sub-structure, a named, auratic persona, to which these memory fragments can be plausibly affixed. (I am suggesting the term "auratic persona," combining [and contrasting] Walter Benjamin's notion of "aura" with Deleuze and Guattari who speak of "conceptual personae"; see Young 2013). It further works because the putative persona serves to conceal something that is simultaneously revealed, namely, the actuality and reality of the memory fragments, miniatures of lived recollection, that are put on full display without being fully identified for what they truly are. What the viewer, uninitiated as s/he remains into the biographical sources of origin of the linguistic and visual elements, engages with is therefore a true representation of realities disguised as falsehoods, much like Jewish tradition treats the surface level of the sacred text of the Torah.

Why Arendt/"Arendt" in the first place? The work is part of a series of putative lives of "great European thinkers" that, at present, also includes "Walter Benjamin" and "Mikhail Bakhtin," in addition to "Hannah Arendt" (for Arendt's take on "greatness", see Arendt 1961, 47.) The choice of personae indicates auratic presences, a pantheon of sorts, mediated by particular names. This onomatopoeic conjuring shines a light on the dialectic of presence and absence, on the vanishing of the recalled. The choice of names-everyone knows, ought to know, ought to have heard and, in fact, read them-focuses attention on the interconnected problems of knowledge-production, transmission, and -inheritance, on both the levels of past knowledge and the making-present (Vergegenwärtigung) of a faux-biographical archive. The name provides a literal vanishing point around which the images and objects are arranged, with the captions providing the thread that connects images and objects to that vanishing point.

Like Arendt with regard to Benjamin (see Arendt 2019, liii-Iv), whose attitude toward collecting value-less objects calls into question the commitment of the collector toward preservation and hence neither confers market value nor intrinsic meaning on the collected objects, so it seems with Shenitzer's Arendt as well. The randomness of the (re-)collected moments, grounded as they may be in memories of unmarked origin, creates a voluminous assemblage that, both, in spite and because of its persuasive range, destabilizes the image evoked by the totality of images and objects. We walk away uncertain of the "take-away" or "cash value" of the encounter.

Another parallel between Arendt's observation on the effect of Benjamin's approach to collecting and Shenitzer's Arendt is the appearance of whimsicality that arises from the utter disregard for "public significance" characteristic of the flâneur:

\footnotetext{
[S]ince this "deepest urge" in the collector has no public significance whatsoever but results in a strictly private hobby, everything "that is said from the angle of the true collector" is bound to appear as "whimsical" as the typically Jean Paulian vision of one of those writers "who write books not because they are poor, but because they are dissatisfied with the books which they could buy but do not like" [...]. (Arendt 2019, liv-IV)
} 
Shenitzer describes humor as a tool she uses to deal with the emotional force of the recollections that provide the sujet as well as the impetus for her work (Shenitzer 2019). In Arendt's reading of Benjamin, the whimsical arises from the recruitment of objects of putative public significance for the purpose of seemingly satisfying a merely private obsession. What confers a peculiar significance on this act of withdrawal is the background of dark times, of "an era of public darkness" (Iv). By eschewing the representation of an actual Arendt, by giving us a simulacrum of biographical actualities instead, by offering moments of uncertain veracity drawn or constructed from real fragments of memory of uncertain provenance, Shenitzer speaks to those dark times without naming them. Herein lies her "collector's" withdrawal from public significance that gives her "putative Arendt" the misleading appearance of mere whimsicality. As Arendt writes about Benjamin,

there [...] appears a disturbing factor to announce that tradition may be the last thing to guide him and traditional values by no means be as safe in his hands as one might have assumed at first glance. (Arendt 2019, iv)

Even more pertinent and perhaps key to Shenitzer's work is another observation Arendt makes about Benjamin as a "collector." In contrast to the traditional private collector who transforms, while preserving, a past for a present, but inadvertently wreaks some sort of destruction upon it ("the heir and preserver unexpectedly turns into a destroyer," Ivi), Benjamin is exempt from this charge of appropriation because he already finds the objects of his interest (children's books, the Shma' Yisrael engraved on two grains of wheat, etc.) already severed from any meaningful tradition. In other words, his manner of collecting indicates, rather than wreaks, destruction. Using this as a possible analogy one may be able to describe the logic of Shenitzer's use of "Arendt" as a persona or an icon that is "collected" or picked up as a "coral or pearls" from the debris washed up on the shores of a post-Holocaust world. By making Hannah Arendt the object of her work of memory collection and rearrangement, preferably displayed within the context of a bourgeois home, a cabinet, a private museum-type setting, she creates a new, appropriated, de- and recontextualized, present/absent figure called "Hannah Arendt" that denies the possibility of asserting authenticity, historicity, or the authority of certain access to tradition or the past.

\section{Staging Dis/Appearance: Shenitzer's Arendt from the perspective of performance theory}

Heeding the maxim that "every artist paints (her)self" (Eisler 1987), Shenitzer's work relinquishes the illusion that it could be otherwise. What appears, then, in the putative life of Hannah Arendt is Shenitzer's autobiography in disguise, a self-portrait in stages, echoes, fragments of the remembered, forgotten, and suggested. Just as Rembrandt might paint himself in historical costume (or like early $20^{\text {th }}$-century modern Ottoman citizens would pose as Palestinian peasants to have their portraits taken by the Armenian photographer across from the Jaffa-Gate), Shenitzer portrays "herself" in the guise of a putative Arendt. The name that provides the focal point is the screen onto which the artist projects a kaleidoscope refracting her own fragmented self. 
In order to "work" as a work of faux-biographical art, the series could have played toward verisimilitude. Shenitzer could have used pseudo-historical photographs instead of drawings, creating simulacra of an actual past. The mixture of drawn images, the handwritten labels, and pseudo-objects mixed in with actual could-be-authentic objects the artist forces the viewer to recognize the installation as contrivance and artifice, disrupting the possibility of illusion. Ready to suspend disbelief, viewers sometimes fail to realize that Shenitzer never signed the compact of illusion.

What is going on here may be illustrated, by way of contrast, in Rebecca Schneider's writing on theatrical reenactment (2011). Schneider vividly describes the impossible mandate and the abiding mystery of theater, which is to make the absent present. The mandate of reenactment is to render a past present and bring it to experience. But the past is past and unavailable, and our means of representation are not just limited, but positively distorting. To have full access to a past would mean to visit it, be in it, live it, as in the fantasy of time travel. ${ }^{7}$ All reenactment-in whatever form of artistic or scholarly production-rests on the acknowledgment that a repetition of the past is neither possible nor desirable. As Schneider describes in relation to one of her examples, the Wooster Group's literal reenactment of an earlier work by Jerzy Grotowski, the more precise the reenactment, the more "eerily false" it rings (112). Schneider, leaning on Dunkelberg (2005), describes the experience as follows: "Indeed, watching the labor of exact replication from the audience, it seems as though the more they get the reenactment exactly right, the more uncannily wrong it begins to feel" (112). If one takes that reenactment of an earlier play, its precise quotation, as one end of a spectrum and places Shenitzer's Putative Arendt on its other end, one may arrive at the following observation. Whereas the Wooster Group's precise imitation of its original feels eerily false, Shenitzer's complete obscuring of the original, to the point of making it vanish, except for the name on which it hangs, feels perplexingly authentic.

More carefully considered, all consciousness of the past is always the present consciousness of a past and hence the index of a present. Reenactment, repetition, imitation, quotation, and the like, when sustained by a compact of illusion and the suspension of disbelief, is then a form of escape into a virtual past, a form of repressing our self-awareness of the present. When art shines a light on this dialectic and disrupts the illusion (as in a Brechtian Verfremdungseffekt), we are reminded that the past, precisely because it is beyond our reach, is at an advantage over the present. All retrieval is purchased at the loss in the values of memory, authenticity, and genuineness. Because of this inevitable loss, promise of access to the past, even illusory access, is so highly prized.

But it is not at all certain that such access is even sought by Shenitzer. In fact, the "real" Hannah Arendt, putatively present in the archive of her writings, letters, images, interviews etc., disappears behind the "putative" archive of faux authentic images, captions, and objects that, at the same time, act as a kind of ghost photography showing material traces of a spirit "Arendt" who oscillates between appearing and disappearing.

Despite the very different means and virtually opposite stance toward the problem of mimesis (one perhaps rooted in a Jewish, rather than Christian, disposition toward the the-horein of 
aesthetic production), Shenitzer complicates the assumptions of sincerity that might be expected in an aesthetic re/production of a deadly serious past. One might say that by using the most "sketchy" of all artistic media (i.e., drawing), and by placing the faux-bios in architectural spaces that evoke the false solidity of late-nineteenth and early-twentieth-century bourgeois spaces of ostentatious arrivistes homes, Shenitzer creates something that is so obviously ironic that it becomes serious: in a secondary seriousness about that which is beyond earnest representation, commemoration, or (G-d forbid) reenactment. In this context, the very suggestion of "camp" attains a different meaning.

\section{Inheritance or appropriation?}

Schneider's wrestling with "reenactment" as a characteristic of mimetic stagecraft is helpful in thinking about the dialectic of inheritance and appropriation. Hannah Arendt, in the preface to Between Past and Future (1961), cites the French poet and writer René Char, to indicate the problem she aims to describe in her own thinking about the space between inherited past and made future, whereby past, present, and future seem to share the property of being public rather than merely private and hence "idiotic" (71). In Arendt's reading, the history of modern revolutions is not so much a continuum, as it might be for Hegel or Marx, rather than a series of moments when men and women were released from the opaque sadness of private lives and placed in that existential space where past and future significantly intersected in lives called upon to regenerate that eminent space that is at the heart of meaningful, i.e. political, life, in the non-trivial sense of the political. Arendt also makes it clear that the "lost treasure" pursued by those who saw themselves placed on the stage of history and in the spotlight of public deeds was ultimately a "mirage," which may be her way of saying, a fiction (Arendt 1961, 4-5).

In the passage quoted by Arendt, Char speaks of an "inheritance without testament." In his words, Notre heritage n'est précédé d'aucun testament (Arendt 1961, 3). Arendt may have been drawn to this quote because of the existentialist implications of an "inheritance without testament." What better illustration of what Heidegger means by "thrownness" (Geworfenheit)!

Our more or less literal appropriations of the past are both inevitable and ethically problematic. It is inevitable for us to appropriate the past, with or without mandate, because without appropriation we would have no language at all, no means of communication, no forms of expression, and nothing to express. It is ethically problematic because of the lack of mandate, in other words, because of our situation "beyond all tradition," a situation diagnosed by Friedrich Nietzsche but more virulently and viscerally experienced as true by the generations who witnessed the destructive forces that led to, and became manifest in, the two World Wars of the twentieth century.

Lack of mandate, thrownness, loss of tradition, and the like mid-twentieth-century tropes of malaise were forcefully rejected by the Jewish philosopher Emil Fackenheim in his later work, post1967, when he began to articulate a new type of mandate, one emerging from Auschwitz. In Fackenheim's reading, Auschwitz revealed, as a matter of absolute moral clarity, the mandate not 
to allow Hitler any posthumous victories. Fackenheim called this the $614^{\text {th }}$-commandment, one more than the 613 commandments rabbinic tradition counted as having been revealed at Sinai. This is how he put it:

\begin{abstract}
Jews are forbidden to hand Hitler posthumous victories. They are commanded to survive as Jews, lest the Jewish people perish. They are commanded to remember the victims of Auschwitz lest their memory perish. They are forbidden to despair of man and his world [...], lest they cooperate in delivering the world over to the forces of Auschwitz. Finally, they are forbidden to despair of the God of Israel, lest Judaism perish. (Fackenheim 1972, 84)
\end{abstract}

This is not the place to critique Fackenheim, even though it may well be asked what it means that he formulated his famous postulate very much in light of, and in response to, a completely different event, namely, the 1967 Six Day War in the Middle East, giving the present moment meaning in light of a past that, to him and many others, all of a sudden seemed repeatable. The imperative he formulated was based on a profound fear of repetition on the historic stage of an event that had to remain unique and, in an eerie sense, divine. In other words, far from representing a simple act of accepting an inheritance or formulating a mandate of the past, Fackenheim's $614^{\text {th }}$ commandment (transgressive as it is, as it is explicitly forbidden in the Torah to add to or subtract from it) is a mandate issued by a present on a past, and hence perhaps another case of appropriation without mandate, inheritance without testament.

Much like the men described by Arendt who were forced to conduct "all relevant business in the affairs of the country [...] in deed and word" and thus "constitute(d) willy-nilly a public realm" (Arendt 1961, 3), Fackenheim's generation found itself in a similar place where, in hindsight, the past was disclosed as issuing a mandate to which one had to respond. Or, rather, the present threat of an unknown future focused the attention of men and women living in a time dominated by "knaves or fools" (Arendt 1961, 3) to act on their own and extract from a fractured past what mandates they could. The reason why Arendt became an outcast from Jewish politics was that she derived different mandates from the same past, usable ones, to be sure, but perhaps not toward the same vision of the future as, say, Fackenheim.

Is Shenitzer's Arendt indicative of a retreat to "the weightless irrelevance of [...] private affairs, once more separated from 'the world of reality'," an expression of "the 'sad opaqueness' of a private life centered about nothing but itself" (Arendt 1961, 4)? In other words, is the life depicted a purely private life, or does the depiction, the choice of name as cipher, the surreptitious revelation of the artist's private moments, also entail the assertion of a mandate emanating from the past, even in its "campy" denial of any relevance of such a possibility? Would this require for the show to be about the "real" historical Arendt? Like Arendt, Shenitzer is compelled to reenact by the existential distance between the past and us, between us and the past. The question is, then, what art can do to draw our attention to that space between past and future that we inhabit. What kind of past, what kind of future? 
Like one of the erstwhile Sabatians and Frankists, who felt mandated to cross over into the world of darkness where the sparks of light are trapped that needed to be redeemed and restored to their proper place, so as to repair the cosmic order shattered in the beginning, Shenitzer feels compelled to lift up the fragments of her own memory, those "coral and pearls," that signify her (and through her artwork now also our) connection to a past that gains its significance from being remembered, represented, reenacted, and, if need be: reinvented, so as to be carried forward. What remains unacknowledged in Fackenheim, namely, the sleight-of-hand by which he attributes the mandate he formulates for the future to the past, becomes visible in Shenitzer's "Arendt." By substituting her own memory fragments for those of an actual Arendt, Shenitzer's putative "Arendt" reenacts and renders present elements of actual pasts to give us the mimetic opportunity to propel ourselves forward, once again, from where "Arendt" stood, to see our present in light of a putative, and hence not necessarily usable, past. This, then, is the "public" side of this work of art: that it reminds us that we retain responsibility for the past precisely because we inherited its various and contradictory mandates.

\title{
Naming the treasure
}

Being without tradition (or testament), we are disconnected or untethered from the past. This, no less than the sudden nameless (because unheralded and unanticipated) gift of freedom obtained by means of revolution described by Arendt, is a condition that lacks a name. Whether or not to treasure it is as uncertain to us as was that gift of freedom obtained by means of revolution, which means by violence. We, the unintentional heirs of a future never heralded by any past, depend on fragments of remembrance that historians no more or less than artists assemble into a treasure chest, to be carried forward. As such we are manufacturing the testament for the future. Arendt resolves the riddle when she translates "treasure" into the historical language proffered by, and used in regard to, those revolutions: public happiness and public freedom, with the emphasis resting on "public." Unbeknownst to themselves, so Arendt, that was what those men in revolutionary times unexpectedly found in their hands: a new, unheralded and unnamed thing that may be called public, or the republic. ${ }^{8}$

Of the situation of the historian of thought Arendt writes as follows:

\begin{abstract}
If one were to write the intellectual history of our century, not in the form of successive generations, where the historian must be literally true to the sequence of theories and attitudes, but in the form of the biography of a single person, aiming at no more than a metaphorical approximation to what actually happened in the minds of men, this person's mind would stand revealed as having been forced to turn full circle not once but twice, first when he escaped from thought into action, and then again when action, or rather having acted, forced him back into thought. (Arendt 1961, 9; emphasis added)
\end{abstract}

What I find intriguing in this statement is the highlighted part of the sentence where Arendt envisages the task of writing history metaphorically, through the prism of a particular life, as "no more than a metaphorical approximation to what actually happened in the minds of men". The 
plural matters in that the individual biography provides the medium or metaphor for what happened in the minds of men, of which the individual is only one among others. It strikes me that this is precisely what Shenitzer does in her "putative life of Hannah Arendt." She picks a name and makes the life she concocts from her own memory fragments a window into what obtained in the lives of those who, like Arendt, were compelled to make certain choices in a particular world and situation. Less confident of what went on in those minds, Shenitzer nevertheless construes a plausible life that, in all its particularity, bears metaphorical character. And just as anticipated by Arendt writing on "in-between" periods, i.e., periods of contemplation rather than action, Shenitzer zeroes in on the world between the wars, the very period of Arendt, Benjamin, and others who found themselves challenged to make sense of the shambles of the past while readying themselves, unbeknownst to themselves, for futures into which they were soon enough propelled, forced from contemplation into action, a future that to us is a fractured past and that reminds us of the preciousness of the short-lived-ness of those moments of reprieve, including our own.

\section{Notes}

\footnotetext{
${ }^{1}$ Ute Frevert is director at the Max Planck Institute for Human Development in Berlin. The remarks I am referring to were made in a speech at Boston University, on October 15, 2018. See http://www.bu.edu/jewishstudies/ calendar/the-elie-wiesel-memorial-lectures/. While Frevert, who studies the history of emotions, spoke of the past, I am extending her observation to the present and to the general question of action in history.

2 "Difficult Freedom" is the title of a collection of writings by French Jewish philosopher Emmanuel Lévinas. See Lévinas (1976) and (1990).

3 See the German Strafgesetzbuch, Paragraph 323c. On the pre-history of this law see Haubrich (2001, 56ff).

${ }^{4}$ The legal principle is often formulated as "ad impossibilia nemo tenetur" or "ultra posse nemo tenetur." See Fellmeth and Horwitz (2009). On Kant, see Milz (2002, 182).

5 "Das man" is the early Heidegger's term for the anonymous force we may call peer pressure, the world of conventional morality, etc.

${ }^{6}$ It is not entirely clear whether misspellings or grammatical errors in the German of the titles and captions are intentional or unintentional, or whether the viewer is meant to take note of them, or how one is to react to them. In this case ("den Ganz" instead of "die Gans" of the original nursery rhyme), the misspelling gave rise to a hilarious (and compelling) interpretation offered by Arendt biographer Thomas Meyer during the opening symposium.

7 Time travel, that wonderful fantasy, is fuelled by its paradoxical impossibility: that the past in which we want to insert ourselves would no longer be the actual past but something new, an alternative past, changed by our having inserted ourselves in it. The visited past is transformed rather than "immortal." See Arendt (1961).
}

${ }^{8}$ A careful glance at the history of early modern political theory reveals that the modern republic was anything but unheralded or unnamed. It appeared in reality after centuries of theorizing the ancient Hebrew republic. 


\section{Works Cited}

"About A Putative Life of Hannah Arendt, Exhibit and Symposium." 2018. Elie Wiesel Center for Jewish Studies, Boston University. http://www.bu.edu/jewishstudies/about-the-exhibit/

Arendt, Hannah. 1961. Between Past and Future: Six Exercises in Political Thought. New York: Viking.

. (1963) 2006. Eichmann in Jerusalem: A Report on the Banality of Evil. New York: Penguin.

___. 2018. Die Freiheit frei zu sein. Munich: dtv.

_-_. 1958. The Human Condition. Chicago: University of Chicago Press.

2019. "Introduction." In Walter Benjamin, Illuminations. Translated by Harry Zohn. Boston: Mariner.

1978. The Jew as Pariah. New York: Grove.

Benjamin, Andrew. 2018. "Being and Appearing: Notes on Arendt and Relationality." Arendt Studies 2: 215-232. https://doi.org/10.5840/arendtstudies20183139

Braun, Günther E. 1975. "'Sollen impliziert können' und der entscheidungstheoretische Kontext." Journal for General Philosophy of Science Zeitschrift für Allgemeine Wissenschaftstheorie 6 (2): 311-330. https://doi.org/10.1007/BF01800792

Derrida, Jacques. 1996. Archive Fever: A Freudian Impression. Translated by Eric Prenowitz. Chicago: University of Chicago Press. https://doi.org/10.2307/465144

Dunkelberg, Kermit. 2005. "Confrontation, Simulation, Admiration: The Wooster Group's Poor Theater." TDR: The Drama Review 49 (3): 43-57. https://doi.org/10.1162/1054204054742444

Encke, Julia. 2018. "Hannah Arendt über Freiheit. Ein unwahrscheinlicher Bestseller." Frankfurter Allgemeine Zeitungi, March 27. https://www.faz.net/aktuell/feuilleton/buecher/autoren/gespraech-ueber-hannah-arendtsbestseller-die-freiheit-frei-zu-sein-15509337.html

Eisler, Colin. 1987. "Every Artist Paints Himself': Art History as Biography and Autobiography." Social Research 54 (1): 73-99.

Fackenheim, Emil. 1972. God's Presence in History. New York: Harper.

Fellmeth, Aarom X., and Maurice Horwitz. 2009. "Ad impossibilia nemo tenetur." Guide to Latin in International Law. Oxford: Oxford University Press. https://doi.org/10.1093/acref/9780195369380.001.0001

Haubrich, Edgar. 2001. Die unterlassene Hilfeleistung. Frankfurt: Peter Lang.

Lévinas, Emmanuel. 1976. Difficile liberté. París: albin michel.

. 1990. Difficult Freedom: Essays on Judaism. Translated by Seán Hand. Baltimore: Johns Hopkins University Press.

Milz, Bernard. 2002. Der gesuchte Widerstreit: Die Antinomie in Kants Kritik der Praktischen Vernunft. Berlin: de Gryuter. https://doi.org/10.1515/9783110881141

Schneider, Rebecca. 2011. Performing Remains: Art and War in Times of Theatrical Reenactment. London: Routledge. https://doi.org/10.4324/9780203852873

Schöndorf, Harald. 1985. '"Denken-Können' und 'Wollen-Können' in Kants Beispielen für den kategorischen Imperativ." Zeitschrift für Philosophische Forschung 39 (4): 549-573.

Shenitzer, Miriam. 2019. "Putative Lives of Great European Thinkers." http://miriamshenitzer.com/putative-livesof-great-european-thinkers/.

Stangneth, Bettina. 2014. Eichmann vor Jerusalem: Das unbehelligte Leben eines Massenmörders. Reinbek bei Hamburg: Rowohlt-Taschenbuch-Verlag.

Strauss, Leo. 2002. The Early Writings. Translated and edited by Michael Zank. Albany, NY: SUNY Press. 
Wolin, Richard. 2001. "Heidegger's Children." The New York Times, December 16, 2001. https://nyti.ms/2HyzUTV 2015. Heidegger's Children: Hannah Arendt, Karl Löwith, Hans Jonas, and Herbert Marcuse. Princeton, NJ: Princeton University Press.

Young, Eugene B. 2013. Deleuze and Guattari Dictionary. New York: Bloomsbury.

\section{Biography}

Michael Zank is Full Professor in the Department of Religion and Director of the Elie Wiesel Center for Jewish Studies at Boston University. He is the author, most recently, of Jerusalem. A Brief History (2018), and Jüdische Religionsphilosophie als Apologie des Mosaismus (2016). http://blogs.bu.edu/mzank

(C) 2019 Michael Zank

(c) (1) Except where otherwise noted, this work is licensed under a Creative Commons Attribution-

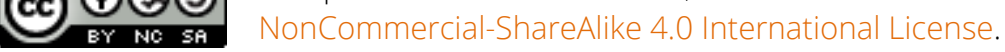

